\title{
TRANSAKSI BENTURAN KEPENTINGAN BAGI DIREKSI PERSEROAN TERBATAS TERHADAP KEGIATAN PASAR MODAL DI INDONESIA
}

\author{
Kiki Latifa Zen, Ngadino, Anggita Doramia Lumbanraja \\ Program Studi Magister Kenotariatan, \\ Fakultas Hukum, Universitas Diponegoro \\ E-mail: kikizen.kz@gmail.com
}

\begin{abstract}
Companies that have already gone public usually want a more substantial source of funds, one of which is by holding capital market activities (share investment), not a few for the Directors of the Company to make a conflict of interest transaction for their interests which results in a loss in a limited company. This paper aims to find out what is the basis for shareholders, Directors and The Board of Commissioners in conducting transactions of conflict of interest. Philosophical normative research approaches are used to analyze conflicts of interest referring to related regulations and principles of agreement in the capital market. As a result of the discussion, with the ambiguous regulations, if there is a conflict of interest by the Directors and other management, each Director must be fully responsible personally (if only one director) for the loss of a Limited Liability Company if the person concerned is proven guilty or negligent in carrying out their duties in accordance with applicable regulations, but in order to avoid conflicts of interest by the board of directors, the Company must establish a Limited Company Assistant and also form an Audit Committee to increase the effectiveness of the internal and external audit functions and the effectiveness of the internal control system to be protected from actions fraudulent company management, which can be detrimental to stock investments.
\end{abstract}

\section{Keywords: transaction; agreement; investation; capital market}

\begin{abstract}
Abstrak
Perusahaan yang sudah mengalami go public biasanya meinginkan sumber dana yang lebih besar salah satunya yaitu dengan cara mengadakan kegiatan pasar modal (Investasi saham), tidak sedikit bagi Direksi Perseroan melakukan transaksi benturan kepentingan untuk kepentingan pribadinya yang berujung pada terjadinya kerugian dalam Perseroan terbatas. Tulisan ini bertujuan untuk mengetahui apa yang menjadi dasar bagi para pemegang saham, Direksi, maupun Dewan Komisaris dalam melakukan transaksi benturan kepentingan tersebut. Pendekatan penelitian normatif filosofis digunakan untuk menganalisis benturan kepentingan mengacu pada peraturan yang terkait dan asasasas perjanjian dalam pasar modal. Sebagai hasil pembahasannya yaitu dengan Peraturan yang masih rancu maka apabila terjadi benturan kepentingan yang dilakukan oleh Direksi maupun pengurus lainnya adalah dengan tiap-tiap Direksi harus bertanggungjawab penuh secara pribadi (apabila direksi hanya satu) atas kerugian Perseroan Terbatas apabila yang bersangkutan terbukti bersalah atau lalai dalam menjalankan tugasnya sesuai dengan ketentuan yang berlaku, namun agar menghindari terjadinya benturan kepentingan yang dilakukan oleh pihak direksi maka Perseroan harus membentuk Asisten Perseroan Terbatas dan juga membentuk Komite Audit untuk meningkatkan efektivitas fungsi audit internal dan eksternal serta efektivitas sistem pengendalian internal agar terlindungi dari tindakan-tindakan curang yang dilakukan pihak manajemen perusahaan, yang mana dapat merugikan investasi saham.
\end{abstract}

Kata kunci : transaksi; perjanjian; investasi; pasar modal 


\section{A. Pendahuluan}

Perkembangan perekonomian bagi Negara yang sedang berkembang seperti di Indonesia, salah satu pemasukan kas Negara yang sangat signifikan adalah dengan mengadakan investasi. Namun investasi memiliki pengertian yang sangat luas yakni mencakup investasi langsung maupun investasi tidak langsung (Harjono, 2007). Kedua jenis investasi tersebut memiliki peranan yang sangat penting dalam pertumbuhan perkenomian di Indonesia. Dalam kamus ekonomi dikemukakan, Investment (investasi) mempunyai 2 makna yakni:

"pertama. Investasi berarti pembelian saham, obligasi dan benda-benda tidak bergerak, setelah dilakukan analisa akan menjamin modal yang dilekatkan dan memberikan hasil yang memuaskan. Faktor-faktor tersebut yang membedakan investasi dengan spekulasi. Kedua. Dalam teori ekonomi investasi berarti pembelian alat produksi (termasuk di dalamnya benda-benda untuk dijual) dengan modal berupa uang"

Oleh karena itu, maka pemerintah memerlukan perangkat hukum yang nasional sesuai dengan hukum perikatan atau kontrak yang berkembang secara dinamis dalam masyarakat demi melengkapi perangkat perundang-undangan. Bentuk pengaturan yang terkait dengan investasi tersebut adalah Undang-Undang Nomor 8 Tahun 1995 tentang Pasar Modal (UU Pasar Modal). Pasar modal sebagaimana pasar pada umumnya adalah tempat dimana bertemunya antara penjual dan pembeli. Di dalam pasar modal aktivitas para pemilik modal dengan pihak yang membutuhkan modal dilakukan dengan melalui perantara pialang efek, dan obyek yang dijual yakni berupa "efek". Berdasarkan Pasal 1 angka 13 UU Pasar Modal menyebutkan bahwa "kegiatan yang bersangkutan dengan penawaran umum dan perdagangan efek, perusahaan publik yang berkaitan dengan efek yang diterbitkannya serta lembaga dan profesi yang berkaitan dengan efek"(Undang-Undang Pasar Modal, 1995).

Pasar modal yang memiliki peran sangat penting terhadap berjalannya kegiatan perekonomian Indonesia yaitu sebagai alternatif sumber pembiayan bagi perusahaan-perusahaan dan alternatif investasi bagi para investor. Namun semua itu tidak terlepas pula dengan para pelaku usaha pasar modal. Dalam menjalankan fungsinya semua pelaku pasar modal dituntut untuk memahami serta menguasai segala system hukum yang menjadi landasan terhadap kemajuan industry pasar modal Indonesia(Surya, 2010).

Suatu kegiatan bisnis memerlukan adanya perjanjian-perjanjian bisnis (business agreement/ business contract) dan hampir segala perjanjian dibuat dalam bentuk tertulis. Perjanjian yang ada dalam KUHPerdata Pasal 1313 menyatakan bahwa "suatu perbuatan yang mana satu orang atau lebih mengikatkan dirinya terhadap satu orang lain atau lebih"(Prof R. 
Subekti S.H, n.d.), Hukum perikatan yang terdapat dalam buku III KUHPerdata merupakan hukum yang bersifat khusus dalam melakukan perjanjian dan perbuatan hukum yang bersifat ekonomis atau perbuatan hukum yang dapat dinilai dari harta kekayaan seseorang atau badan hukum. Adapun istilah umum dalam perjanjian yaitu kontrak secara gramatikal, istilah kontrak berasal dari bahasa Inggris, contract baik perjanjian maupun kontrak mengandung pengertian yang sama, yaitu suatu perbuatan hukum yang mengikat. Akan tetapi istilah kontrak lebih sering digunakan dalam praktek-praktek bisnis.

Kegiatan yang dilakukan di pasar modal tentunya berkaitan dengan perusahaan publik atau dikenal sebagai emiten yang merupakan salah satu pelaku dari pasar modal. Emiten merupakan perusahaan yang pada umumnya berbentuk Perseroan Terbatas yang sudah go public dan berkeinginan memperoleh dana melalui pasar modal dengan cara melakukan penawaran umum yakni dalam rangka menjaring dana bagi kegiatan usaha perusahaan atau pengembangan usaha perusahaan, transaksi yang kemungkinan besar dihindari Emiten adalah Benturan Kepentingan tertentu. Dalam hal ini, dikarenakan transaksi yang berbeda kepentingan ekonomis perusahaan dengan kepentingan ekonomis anggota Direksi, anggota Dewan Komisaris, atau pemegang saham utama tidak dapat dilakukan dengan mudah. Salah satu cara untuk disetujuinya kegiatan tersebut adalah dengan persetujuan dari pemegang saham independen, sesuai yang diatur dalam Angka 3 huruf a Keputusan Ketua Bapepam No. Kep-412/BL/2009, (Peraturan No.IX.E.1) menentukan bahwa transaksi yang mengandung benturan kepentingan wajib tersebih dahulu disetujui oleh Pemegang Saham Independen atau wakilnya mereka yang diberi wewenang untuk itu dalam hal ini Rapat Umum Pemegang Saham (RUPS).

Kecenderungan perjanjian yang tertulis ini dibuat oleh salah satu pihak yang kuat posisi ekonominya. Kepentingan ekonomi yang ada di dalam masyarakat begitu luas, mulai dari kepentingan pribadi hingga kepentingan masyarakat dengan negara, maka dari itu penggolongan hukum privat mengatur kepentingan individu, seperti hukum dagang dan hukum perdata. Suatu perusahaan publik yang pada umumnya berbentuk PT tentunya memiliki organ-organ di dalamnya, yakni RUPS, Direksi, Dewan Komisaris, dengan tugas dan tanggung jawab yang berbeda setiap posisinya(Simanjuntak, et.,al., 2009).

Karena adanya perbedaan posisi serta tanggung jawab tersebut maka sering kali terdapat perbedaan yang berujung pada terjadinya benturan kepentingan antara pemegang saham dengan pengurus PT. namun dengan terjadinya transaksi benturan kepentingan tersebut maka dapat menimbulkan segala kerugian yang diterima oleh pihak PT. untuk mengantisipasi hal tersebut 
maka perlulah diatur ketentuan terkait benturan kepentingan transaksi tertentu dalam pasar modal.

Pengaturan transaksi yang mengandung benturan kepentingan ditujukan untuk mendorong akuntabilitas pengelolaan perseroan. Perusahaan yang membutuhkan kecepatan dalam proses pengambilan keputusan mengingat peluang bisnis selalu diperebutkan. Oleh karena itu, pengambilan keputusan bisa mendatangkan keuntungan tetapi tidak menutup kemungkinan jika dikemudian hari mendatangkan kerugian. perusahaan harus melibatkan pemegang saham yang tidak terkait dengan transaksi, untuk dimintakan persetujuan sehingga risiko yang harus ditanggung perusahaan dapat dikalkulasikan secara matang oleh pemegang saham demi untuk menjaga kejujuran, serta pengambilan keputusan untuk transaksi yang mengandung benturan kepentingan tertentu yang akan mendatangkan kerugian. Perusahaan tidak akan dipersalahkan untuk transaksi tersebut, tetapi hal itu juga harus dibuktikan dengan risalah atau notulen rapat umum pemegang saham

Berdasarkan uraian tersebut diatas, penulis tertarik untuk mengetahui dan mengkaji suatu permasalahan hukum dalam bentuk skripsi dengan judul: "Transaksi Benturan Kepentingan Bagi Direksi Perseroan Terbatas Terhadap Kegiatan Pasar Modal Di Indonesia”

Berdasarkan uraian latar berlakang permasalahan di atas, maka permasalahan yang dikaji pada penelitian ini adalah mengenai situasi di dalam pasar modal di Indonesia apakah setiap transaksi yang mengandung benturan kepentingan selalu dikategorikan sebagai suatu transaksi benturan kepentingan, serta bagaimana perlindungan hukum dalam suatu transaksi yang mengandung benturan kepentingan dan siapa yang harus bertanggungjawab terhadap terjadinya benturan kepentingan tersebut.

Kerangka teori adalah cara bagi seorang peneliti untuk mengaplikasikan pola berpikirnya dalam menyusun secara sistematis. Sebagaimana diterjemahkan oleh Soerjono Soekanto (Soekanto, 1981), Kerlinger mengartikan teori sebagai seperangkat konstruksi, konsep, definisi dan prosisi yang saling terkait, yang menggambarkan suatu pandangan sistematis tentang fenomena dengan cara menetapkan atau menegaskan hubungan antara dua variable, dengan maksud menjelaskan dan meramalkan fenoma tersebut (Ngani, 2012). Kerangka Teori yang digunakan dalam penulisan ini ialah teori perlindungan hukum dan teori efektivitas hukum.

Menurut Satjipto Raharjo, Perlindungan hukum adalah suatu perlindungan yang diberikan kepada subyek hukum. baik yang bersifat prefentif maupun represif, lisan maupun tertulis, pengayoman kepada setiap hak asasi manusia yang dirugikan oleh orang lain maupun dalam hal 
ini adalah perusahaan, agar subyek hukum dapat menikmati semua hak-hak yang diberikan oleh hukum. (Setiono, 2004).

Prinsip perlindungan hukum bagi masyarakat Indonesia ada pada pancasila dan konsep Negara Hukum, kedua sumber tersebut mengutamakan pengakuan serta penghormatan terhadap harkat dan martabat manusia.

Teori selanjutnya yaitu teori efektivitas hukum, bahwa efektif tidaknya hukum dilihat dari norma-norma yang ada di masyarakat, apabila berbicara tentang efektifitas hukum maka berbicara teori hukum yang dikemukakan oleh Gustav Radbrugh, dimana gustav mengkombinasikan ketiga pandangan klasik (filsufis, normative, empiris) menjadi suatu pendekatan dan masing-masing pendekatannya dijadikan sebagai unsur pokok dan menjadi dasar pendekatan hukum yang dikenal sebagai tiga nilai dasar hukum yang meliputi; keadilan (filsufis), kepastian hukum (juridis), dan kemanfaatan bagi masyarakat (sosiologis).

Untuk memperkuat penelitian ini maka diperlukan kajian terhadap penelitian terdahulu yang diharapkan akan memaksimalkan penulisan yang dibuat. Kemudian disebutkan penjabaran faktor pembeda antara fokus penelitian penulis dan fokus penelitian terdahulu yang menjadi sebagai bahan rujukan penulisan ini. Nadya Primaasha Brahmana membahas tentang bagaimana wewenang dan tanggungjawab direksi, ketentuan benturan kepentingan transaksi tertentu, tanggungjawab direksi terhadap benturan kepentingan tertentu (brahmana, 2018). Linda Marietha Sembiring membahas tentang bagaimana kedudukan direksi, tindakan direksi dalam kategori transaksi yang mengandung benturan kepentingan serta upaya mengatasi terjadinya benturan kepentingan Direksi dengan perseroan (Sembiring, 2008).

\section{B. Metode Penelitian}

Metode pendekatan yang dipergunakan oleh penulis dalam penulisan hukum ini adalah yuridis normatif. Penulis melakukan kajian terhadap peraturan perundang-undangan (hukum normatif) yang berlaku, yakni mengenai azaz-azaz hukum. Oleh karena itu studi yang dilakukan oleh peneliti adalah berupa studi literatur/kepustakaan.

\section{Hasil Pembahasan}

\section{Transaksi yang Mengandung Benturan Kepentingan}

Pelanggaran yang masih banyak terjadi di masyarakat dan sering kali ditemukan di pasar modal yaitu terkait dengan benturan kepentingan dalam pasar modal, transaksi yang mengandung benturan kepentingan itu apabila Transaksi perdagangan efek dilakukan di bursa 
efek, yaitu pasar dimana efek (diantaranya saham) diperdagangkan. Transaksi ini dapat dilakukan di pasar reguler dan pasar non reguler. Pasar reguler dijalankan dengan prinsipprinsip standar baik dari cara penawaran dan besarnya harga (tick size) yang harus dilakukan, jumlah satuan transaksi untuk efek (lot size) yang ditransaksikan, serta bagaimana penyelesaian atas transaksi tersebut dilakukan (pujiyanti, Yanti Lasmini., Abubakar, 2018). Eksistensi dan validitas sebuah Perseroan tidak akan terancam oleh kematian, kepailitan, penggantian atau pengunduran diri pemilik atau pemegang saham karena entitas yang berbeda.(separate and distinct from its owner) (Isfardiyana, 2017).

Pada umumnya pemegang saham independen adalah pemegang saham yang tidak terintervensi terhadap benturan kepentingan dari pemegang saham lain sehubungan dengan suatu transaksi tertentu yang memanfaatkan jabatan sebagai anggota Direksi, anggota Dewan Komisaris atau pemegang saham utama yang mempunyai benturan kepentingan atas transaksi tertentu demi mendapatkan keuntungan. Benturan kepentingan pada Angka 1 huruf e Peraturan Nomor IX.E.1 menyatakan bahwa:

"Benturan kepentingan adalah perbedaan antara kepentingan ekonomis Perusahaan dengan kepentingan ekonomis pribadi anggota Direksi, anggota dewan komisaris, atau pemegang saham utama yang dapat merugikan perusahaan dimaksud"(Bapepam-LK, 2008)

Dalam hal terdapat keadaan di mana terjadi perkara di pengadilan antara Perseroan Terbatas dengan anggota direksi yang bersangkutan; atau anggota direksi yang bersangkutan mempunyai benturan kepentingan dengan perseroan terbatas, yang berhak mewakili perseroan adalah: (Nadapdap, 2014).

a) Anggota Direksi yang tidak memiliki benturan kepentingan dengan perseroan terbatas;

b) Dewan Komisaris atau;

c) Pihak lain yang ditujukan oleh RUPS.

Peraturan ini memberikan batasan pengambilan keputusan oleh pihak-pihak yang berkuasa seperti pemegang saham mayoritas, dan komisaris perseroan untuk bersepakat mengenai transaksi tertentu yang memberikan keuntungan kepada pihak-pihak tersebut dengan mengabaikan hak dan kepentingan pemegang saham minoritas, namun pada dasarnya ketentuan mengenai transaksi yang mengandung benturan kepentingan tertentu bersifat preventif, dengan menerapkan prinsip keterbukaan sebagai suatu asas fundamental di dalam pasar modal dan lebih memberdayakan pemegang saham minoritas dan sekaligus mendidik mereka agar memahami haknya untuk dapat melakukan tindakan pencegahan atau mengurangi kemungkinan terjadi hal-hal yang tidak diinginkan dikemudian hari. 
Seorang Direktur dalam menjalankan tugasnya di Perseroan tidaklah boleh melakukan Benturan Kepentingan, sebab, jika terjadi tindakkan Direktur disangsikan tidak objektif lagi dan tidak melaksanakan kepentingan Perseroan. Karena itu, jika seseorang melakukan transaksi yang mengandung Benturan Kepentingan dikatakan bahwa Direktur tersebut telah melanggar prinsip fiduciary duties yang berlaku kepadanya (Marsella, 2016).

Di beberapa Negara terdapat kewajiban bagi perusahaan go public untuk memperoleh persetujuan dari pemegang saham utama dengan perusahaan. Hal ini dimaksud agar pemegang saham utama lebih menggunakan aset-aset perusahaan, informasi, pengaruh, serta perebutan oportunitis perusahaan, sehingga transaksi benturan kepentingan tersebut dapat terjadi. Dengan adanya persetujuan dari pemegang saham minoritas atas transaksi yang dilakukan antara pemegang saham utama dengan perusahaan akan membawa dampak bagi pihak yang menggugat transaksi tersebut untuk membuktikan adanya ketidakwajaran dalam transaksi tersebut.

Transaksi yang dilakukan demi kepentingan ekonomis pihak-pihak tertentu mengandung penilaian harga transaksi yang tidak wajar, ada dua kemungkinan, pertama penilaian itu melebihi harga yang sebenarnya (mark-up), atau penilaian dibuat jatuh dibawah harga wajar yang ukurannya adalah harga besar. Nilai transaksi yang tidak wajar akan menimbulkan resiko kerugian bagi perusahaan. Oleh karenanya, keterlibatan pemegang saham independen dan kewajiban keterbukaan dalam proses pengambilan keputusan untuk transaksi akan mampu memberikan jaminan bahwa transaksi tersebut tidak akan manimbulkan resiko kerugian. Atau kalaupun ada resiko atas transaksi tersebut, pemegang saham independen telah mengetahui dengan cukup (well-informed) mengenai resiko transaksi karena direksi telah memaparkanya secara terbuka.

Jenis-jenis transaksi yang dapat dikategorikan sebagai transaksi yang mengandung benturan kepentingan antara lain adalah: (Bapepam-LK, 2008).

1) Penggabungan usaha, pembelian saham, peleburan usaha, atau pembentukan usaha patungan;

2) Perolehan kontrak penting;

3) Pembelian atau kerugian penjualan aktiva;

4) Pengajuan untuk pembelian efek perusahaan lain;

5) Memberi pinjaman kepada perusahaan lain dengan posisi direktur, komisaris, pemegang saham utama atau perusahaan terkendali dari perusahaan publik juga menjabat sebagai pemegang saham, direktur atau komisaris pada perusahaan lain tersebut.;

6) Memperoleh pinjaman dari perusahaan lain;

7) Melepaskan aktiva perusahaan publik kepada perusahaan lain;

8) Mengalihkan aktiva perusahaan publik kepada pihak lain; 
9) Memakai jasa perusahaan lain;

10) Membeli saham perseroan lain dimana pemegang saham utama, direksi atau komisaris dari perusahaan publik menjadi pemegang saham, anggota direksi atau komisaris dari perusahaan lain tersebut.

11) Melakukan penyertaan pada perusahaan lain;

12) Menggunakan fasilitas pada perusahaan publik oleh perusahaan lain baik afiliasi ataupun bukan;

13) Transaksi lain yang berindikasi adanya benturan kepentingan"

\section{Perlindungan Hukum terhadap Direksi dan Pemegang Saham}

Para pemegang saham, baik secara individu maupun secara kolektif, yang memiliki saham perseroan terbatas berjumlah sampai dengan 1/10 (sepersepuluh) dari seluruh jumlah saham yang dikeluarkan oleh Perseroan Terbatas, bentuk perlindungan hukum bagi pemegang saham biasanya dengan Personal Right (Hak Perseorangan); Appraisal Right (Hak menilai Harga Saham); Pre-emptive Right (Hak Utama); Derivative Right (Hak Derivatif); Enqueterecht (Hak Pemeriksaan) (Wilamarta, 2002). Perihal perlindungan terhadap pemegang saham yang minoritas terhadap tindakan yang tidak wajar dan tidak adil tersbeut, tidak hanya terbatas pada tindakan dari pemegang saham payoritas, melainkan juga terhadap direksi maupun dewan komisaris. Undang-Undang menentukan bahwa pemegang saham minoritas selain mempunyai hak untuk mengajukan gugatan, juga mempunyai hak untuk melakukan tindakan derivative, misalnya direksi atau komisaris telah lalai dalam kewajibannya terhadap perseroan terbatas, maka pemegang saham dapat "mengambil alih" demi kepentingan perseroan.

Berdasarkan atas pertanggungjawaban perusahaan dari pemegang saham dan pemilik selaku pemegang saham mayoritas dalam keadaan normal pemegang saham tidak bertanggungjawab atas kesalahan yang dilakukan korporasi. Mereka seringkali menikmati ketiadaan tanggungjawab secara hukum, hal ini merupakan wilayah abu-abu yang seringkali meloloskan mereka dari jeratan hukum (Handaruprasetyo, 2011). Pengawasan di bidang industri jasa keuangan pasar modal mengalami perubahan dari pengawasan yang dilakukan oleh Bapepam-LK menjadi diawasi oleh Otoritas Jasa Keuangan. Secara kelembagaan, Bapepam-LK bertanggung jawab kepada Menteri Keuangan, karena Bapepam-LK berada di bawah naungan Kementrian Keuangan, sedangkan Otoritas Jasa Keuangan bertanggung jawab kepada Dewan Perwakilan Rakyat atau masyarakat. Aspek krusial yang menjadi dasar pembentukan OJK adalah tidak maksimalnya perlindungan kepentingan konsumen jasa keuangan(Dimyati, 2014). 
Dalam Anggaran Dasar hanya disebutkan nama pemegang saham mayoritas dan nama direktur masing-masing menyebutkan nama pemegang saham mayoritas. Kalau Anggaran Dasar demikian sudah lazim di dalam praktik, berarti kedudukan ketiga organ Perseroan sebagai kedudukan yang harus independen tidak menjadi ketentuan yang memaksa harus ditaati.

Terdapat beberapa alasan pentingnya perlindungan pemegang saham minoritas dalam perusahaan terbuka, di antaranya adalah bahwa perlindungan pemegang saham minoritas merupakan bagian dari pelaksanaan good corporate governance, upaya menjaga kepercayaan investor dan masyarakat, serta menghindari penyalahgunaan oleh pemegang saham mayoritas(Nasution, Wina Bismar., Suhaidi., Siregar, 2018). Dalam UUPT, organ yang ditetapkan untuk mendukung fungsi badan hukum adalah RUPS, Direksi dan Dewan Komisaris. Baik Direksi maupun Komisaris diharuskan menjalankan tugasnya dengan itikad baik dan penuh tanggung jawab. Setiap anggota Direksi bertanggung jawab penuh secara pribadi jika ia bersalah atau lalai dalam menjalankan tugas-tugasnya, begitu juga Komisaris(Undang-Undang Perseroan Terbatas Nomor 40 Tahun 2007, n.d.). Namun, organ perseroan RUPS, Direksi dan Komisaris belum memberikan jaminan terlaksananya prinsipprinsip corporate governance, khususnya mengenai perlindungan investor(Indra Surya, 2008). Untuk lebih menjamin perlindungan pemegang saham minoritas dan meningkatkan tata kelola perusahaan yang baik, maka keberadaan organ-organ tambahan dalam struktur perseroan sangat diperlukan, seperti Komisaris Independen, Komite Audit dan Sekretaris Perusahaan. Dalam hubungannya dengan hal tersebut, Peraturan Otoritas Jasa Keuangan Nomor 33/POJK.04/2014 tentang Direksi dan Dewan Komisaris Emiten atau Perusahaan Publik (selanjutnya disebut "POJK Nomor 33/POJK.04/2014") telah mewajibkan adanya Komisaris Independen dalam jajaran Dewan Komisari(Peraturan Otoritas Jasa Keuangan Nomor 33/POJK.04/2014, 2014).

Di Indonesia Dewan Komisaris merupakan organ yang bersifat pasif dan tidak dapat menjalankan fungsi pengawasannya secara efektif terhadap Direksi, atau sebaliknya, peran Komisaris yang terlalu kuat dalam perusahaan, sehingga seringkali melakukan intervensi terhadap kebijakan Direksi. Sikap yang mengintervensi setiap kebijakan yang diambil Direksi tersebut pada akhirnya akan dapat merugikan kepentingan pemegang saham (minoritas) serta para stakeholder lainnya.

Direksi maupun Dewan Komisaris memang memiliki fiduciary duty yang timbul dari hubungan fiduciary untuk memperhatikan kepentingan perusahaan secara sungguh - sungguh. 
Fiduciary duty Direksi maupun Komisaris terdiri dari duty skill and care, duty to loyalty, no secret profit rule doctrine of corporate opportunity. Namun, praktik yang terjadi kerap kali Direksi maupun Dewan Komisaris ini memanfaatkan perusahaan untuk kepentingan pribadi sehingga tidak cukup hanya berdasarkan doktrin semata. Lebih lanjut, POJK Nomor 33/POJK.04/2014 melalui Pasal 28 ayat (4) juga mewajibkan Dewan Komisaris untuk membentuk Komite Audit.

Komite Audit ini dibentuk oleh Dewan Komisaris untuk melakukan pemeriksaan atau penelitian yang dianggap perlu terhadap pelaksanaan fungsi Direksi dalam melaksanakan pengelolaan perusahaan serta melaksanakan tugas penting berkaitan dengan sistem pelaporan keuangan. Dengan adanya Komite Audit diharapkan mampu meningkatkan efektivitas fungsi audit internal dan eksternal serta efektivitas sistem pengendalian internal sehingga pemegang saham minoritas terlindungi dari tindakan-tindakan curang yang dilakukan pihak manajemen perusahaan, yang mana dapat merugikan investasi yang telah diikutsertakan pemegang saham minoritas ke dalam perusahaan tersebut. Selanjutnya, selain Komisaris Independen dan Komite Audit, keberadaan Sekretaris Perusahaan juga diwajibkan dalam suatu perusahaan terbuka (Pasal 2 ayat (1) Peraturan Otoritas Jasa Keuangan Nomor 35/POJK.04/2014 tentang Sekretaris Perusahaan Emiten atau Perusahaan Publik. Keberadaan Sekretaris Perusahaan ini dinilai sangat penting karena segala data maupun laporan yang sifatnya material ada pada Sekretaris Perusahaan tersebut.

Penerapan prinsip keterbukaan dan pemberdayaan pemegang saham independen merupakan suatu langkah preventif. Tindakan preventif jauh lebih baik. Namun, pemegang saham perlu memahami hak dan juga harus menggunakan haknya untuk melindungi kepentingan secara proaktif. Memang UUPT menyebutkan direksi dan juga komisaris bertanggungjawab secara terbatas sepanjang tindakan tersebut berada dalam wewenangnya (intra vires). Namun pertanggungjawaban dapat dimintakan kepada pengurus jika tindakan pengurus tersebut merupakan tindakan di luar kewenangannya (ultra vires) yang merupakan bertentangan dengan ketentuan dan tindakan itu menimbulkan kerugian bagi perseroan. Kewenangan tersebut bisa saja dipergunakan secara tidak tepat karena kesengajaan atau kelalaikan dalam kaitannya dengan benturan kepentingan transaksi tertentu.

Setiap Direksi harus bertanggungjawab penuh secara pribadi atas kerugian Perseroan Terbatas apabila yang bersangkutan terbukti bersalah atau lalai dalam menjalankan tugasnya sesuai dengan ketentuan. Karena dalam praktik biasanya agak sulit untuk membedakan mana suatu perbuatan yang benar-benaer dilakukan dengan itikad baik dan mana perbuatan yang 
memang sudah sewajarnya dalam menjalankan tugasnya. Pada umumnya setelah Perseroan Terbatas mengalami kerugian, maka saat itu barulah dapat diketahui baik atau buruknya perbuatan direksi.

\section{Simpulan}

Adanya transaksi dengan aktifitas yang mengandung benturan kepentingan, maka tanggungjawab yang diberikan kepada direksi, dewan komisaris, maupun pemegang saham lainnya harus terus di perhatikan, karena apabila perseroan mengalami kerugian karena perbuatan direksi ataupun pengurus lainnya perusahaan bukan hanya mengalami kerugian namun dampak terburuknya perusahan juga dapat di pailitkan.

Penegakan hukum mengenai adanya transaksi benturan kepentingan yang dilajukan oleh direksi belum terlalu jelas dilaksanakan, begitu pun dengan peraturan yang masih harus terus dikaji ulang agar perusahaan dan para pemegang saham lainnya tidak di rugikan.

\section{DAFTAR PUSTAKA}

\section{Buku-Buku}

Brahmana, N. P. (2018). Tanggung Jawab Direksi Terhadap Benturan Kepentingan Pada Transaksi Tertentu Dalam Pasar Modal Berdasarkan Undang-Undang Pasar Modal dan Undang-Undang Perseroan Terbatas.

Cornelius Simanjuntak dan Natalic Mulia. (2009). Organ Perseroan Terbatas. Jakarta: Sinar Grafika.

Dhaniswara K. Harjono. (2007). hukum penanaman modal. jakarta: RajaGrafindo persada.

Indra Surya, I. Y. (2008). Penerapan Good Corporate Governance Mengesampingkan Hak-hak Istimewa Demi Kelangsungan Usaha. jakarta: Kencana.

Nadapdap, B. (2014). Hukum Perseoran Terbatas berdasarkan Undang-Undang Nomor 40 tahun 2007. Jakarta: Penerbit Aksara.

Nico Ngani. (2012). Metode Penelitian dan Penulisan Hukum. Yogyakarta: Tim Pustaka Yustisia.

pujiyanti, Yanti Lasmini., Abubakar, L. (2018). Perlindungan Hukum Bagi Investor Sehubungan Dengan Adanya Pengalihan Kepemilikan Efek Dalam Transaksi Repo Di Pasar Modal. Jurnal Hukum Kenotariatan Dan Ke-PPAT-An, 1(2), 154-155.

Sembiring, L. M. (2008). kedudukan direksi dalam hal terjadinya benturan kepentingan dalam suatu perusahaan. Program Pascasarjana Universitas Sumatera Utara.

Setiono. (2004). Rule Of Law (Supremasi Hukum). Surakarta: Magister Ilmu Hukum Universitas 
Sebelas Maret.

Surya, M. I. N. dan I. (2010). Aspek Hukum Pasar Modal Indonesia. jakarta: Kencana Prenada Media group.

Wilamarta, M. (2002). Hak Pemegang Saham Minoritas dalam Rangka Good Corporate Govermance. Jakarta: Program Pascasarjana fakultas Hukum Universitas Indonesia.

\section{Artikel Jurnal}

Dimyati, H. (2014). Perlindungan Hukum Bagi Investor Dalam Pasar Modal. Jurnal Cita Hukum, 2(no.2), 341.

Handaruprasetyo, Y. T. (2011). Hukum dan Pelaku Investasi Dalam perbankan. Jurnal Hukum, 40 (no.3), 361.

Isfardiyana, S. H. (2017). Business Judgement Rule Oleh Direksi Perseroan. Jurnal Panorama Hukum, 2 (no.1), 2.

Marsella. (2016). Benturan kepentingan Tidak Langsung Oleh Direktur Dalam mengelola Perseroan Terbatas. Jurnal Hukum2, 3(1), 29.

Nasution, Wina Bismar., dan Suhaidi., Siregar, M. (2018). Analisis Yuridis Perlindungan Hukum terhadap Pemegang Saham Minoritas Dalam perusahaan Terbuka. USU Law Jurnal, 6(5), 165 .

\section{Undang-undang dan Peraturan}

Bapepam-LK. Keputusan Ketua Badan Pengawas Pasar Modal dan Lembaga Keuangan tentang Transaksi Afiliasi dan Benturan Kepentingan TransaksiTertentu. , Pub. L. No. Nomor: KEP-412/BL/2009.

Peraturan Otoritas Jasa Keuangan Nomor 33/POJK.04/2014. , Pub. L. No. nomor 33/pojk.04/2014 (2014).

Prof R. Subekti S.H, R. T. Kitab Undang-Undang Hukum Perdata.

Undang-Undang Pasar Modal. , Pub. L. No. Nomor 8 (1995).

Undang-Undang Perseroan Terbatas Nomor 40 Tahun 2007. 